\title{
Larval development of Physocephala (Diptera, Conopidae) in the bumble bee Bombus morio (Hymenoptera, Apidae)
}

\author{
Fábio C. Abdalla ${ }^{1,2}$, Guilherme Sampaio ${ }^{1}$, Marina Pedrosa ${ }^{1}$, Thamiris P. Sipriano, \\ Caio Eduardo C. Domingues ${ }^{1}$, Elaine Cristina M. Silva-Zacarin ${ }^{1} \&$ Daiane A. de Camargo ${ }^{1}$
}

\footnotetext{
'Laboratório de Biologia Estrutural e Funcional (LABEF) - Departamento de Biologia, Universidade Federal de São Carlos, Campus Sorocaba, 18052-780, Sorocaba, SP, Brazil.

2Corresponding author: fadballa@ufscar.br
}

\begin{abstract}
Larval development of Physocephala (Diptera, Conopidae) in the bumble bee Bombus morio (Hymenoptera, Apidae). In the summer of 2012, a high incidence of conopid larvae was observed in a sample of female B. morio collected in remaining fragments of semidecidual forest and Cerrado, in the municipality of Sorocaba, state of São Paulo, Brazil. The larval development of conopid flies was studied, beginning at the larval instars (LO to L3) and PUP, until the emergence of the imago under laboratory conditions and inside the host. At the first instar, or LO, the microtype larvae measured less than $1 \mathrm{~mm}$ in length. During the transition from L1 to L3, the larvae grew in length. At L3, the larvae doubled their length $(4 \mathrm{~mm})$ and then started to develop both in length and width, reaching the PUP stage with $10 \mathrm{~mm}$ in length and $7 \mathrm{~mm}$ in width. The main characteristic that differentiates L3 from the early instars is the larger body size and the beginning of posterior spiracle development. The development from PUP to puparium took less than 24h. The bees died ten days after the fly oviposition, or just before full PUP development. The early development stages (egg-LO to L1) were critical for larva survival. The pupa was visible between the intersegmental sternites and, 32 days after pupation, a female imago of Physocephala sp. emerged from one bee. The puparium and the fly measured approximately $10 \mathrm{~mm}$ in length. In a single day of collection, up to $45 \%$ of the bumble bees collected were parasitized by conopid flies.
\end{abstract}

KEYWORDS. Conopidae; Insecta; larva; parasitism; Physocephala.

Bumble bees comprise about 240 species exhibiting primitively eusocial behavior and which are of vital ecological importance (Williams 1982, 2005). They help maintain the diversity and abundance of many plant species in natural forests, agricultural and also in urban areas. Their potential as long-distance pollinators allows them to visit numerous flowerings before returning to the nest. These bees are large and withstand a large load of pollen during foraging, even under adverse climate conditions (Cortopassi-Laurino et al. 2003, 2006; Klein et al. 2007; FAO 2008). Additionally, they have specialized anatomical structures that ensure them great efficiency in pollination, such as the long glossa that allows them to reach flowers with long tubular corolla. The behavior and anatomic characteristics of the genus Bombus is extremely important to increase variability and productivity in some plant species, such as tomatoes (Aldana et al. 2007).

Only six species of the genus occur in Brazil, which makes it an area of peripheral distribution of Bombus (Sakagami 1976; Michener 2000). The species B. (Fervidobombus) morio (Swederus, 1787) and B. pauloensis Friese, 1913 are abundant in southern and southeastern Brazil, where their distributions overlap. Bombus morio is distributed from northwestern South America to eastern Brazil, Uruguay and northern Argentina (Abrahamovich et al. 2004). These species occur in tropical and subtropical forests and Cerrado, as well as in moderately dry regions (Moure \& Sakagami 1962).
Similarly to Apis mellifera Linnaeus, 1758, sudden decline and loss of entire populations of several species of the Bombus are recorded annually, especially in the European and American continents (Biesmeijer et al. 2006; Martins \& Melo 2010; Cameron et al. 2011). From 1950 to 2000, 13 species of Bombus disappeared from Eastern European countries; four of these are considered extinct (Kosior et al. 2007). In North America, since 1940, the species B. borealis Kirby, 1837, B. terricola Kirby, 1837 and B. variabilis (Cresson, 1872) have declining populations in the state of Illinois, USA (Grixti et al. 2009) and the same happened with the species B. affinis Cresson, 1863, B. fraternus (Smith, 1854), B. pensylvanicus (De Geer, 1773) and B. vagans Smith, 1854 (Grixti et al. 2009; Cameron et al. 2011). The species B. affinis has disappeared from the state of Illinois and populations of the species are practically no longer found in regions where they used to be found in abundance; the same is true for Canada (Cameron et al. 2011).

In Brazil, specifically in the state of Paraná and in some localities in the state of Santa Catarina, the decline, followed by disappearance, of the species B. bellicosus Smith, 1879 was reported by Martins \& Melo (2010). The causes for such drastic decrease in the species' population are diverse, but all authors are in consensus that global warming, intensive agricultural activity and industrialization are the main causes of such phenomenon (Pywell et al. 2006; Grixti et al. 2009). 
The intensification of use of pesticides and herbicides, which are released indiscriminately in the environment without any treatment, can affect the whole entomofauna. Industrial toxic waste changes all ecosystems; consequently, the geobotanic ecosystem and, therefore the balance between opportunistic parasites and their hosts. Parasites may predominate in such condition, becoming a potential threat for bumble bees (Evans et al. 2008; Santos et al. 2008; De Jong 2009; Plischuk et al. 2009; Martins \& Melo 2010; Cameron et al. 2011).

Marcondes et al. (2011) have found an apparently high prevalence of dipteran larvae in both $B$. morio and $B$. pauloensis (cited as $B$. atratus). The authors reported the occurrence of fly larvae taxonomically similar to tachinids. However, more detailed studies, including rearing hosted bees under controlled conditions, have revealed that the parasitoid species were Conopidae microtype larvae. Its development inside adults of $B$. morio is the subject of the present study. Conopids are a worldwide dipteran family that typically parasitizes adult aculeate Hymenoptera, mainly bees and wasps. Many species present specialization of larval development, having Bombus as their main host (SchmidHempel \& Schmid-Hempel 1996). From the microtype egg to imago, three larval instars were described for the observed specimens: $1^{\text {st }}, 2^{\text {nd }}$ and $3^{\text {rd }}$ instars. For some fly families, the prepupa stage is not well characterized. Prepupa is the transition stage between larva and pupa and the main marked event in such stage is larval defecation, with the opening of the midgut and hindgut that remains closed until the end of the larval stage. Some authors describe the prepupation in detail for non-conopid species (Anderson 2000). However, Schmid-Hempel \& Schmid-Hempel (1996) mention a fourth stage, or PUP, in conopid fly larva, studying the same genus as this paper, Physocephala rufipes (Fabricius, 1781). They describe the PUP stage as "fully grown third instar larva just before pupation, i.e. just before host had died"'. The conopid larva loses many adaptive anatomical characteristics for protection, when compared to other dipteran larva, since the egg is oviposited into the bee host's abdomen and develops in a relative safe environment. The eggs are classified as microtype and the larva has thin and translucent integument.

Although studies have reported low incidence of these parasitic flies in the same fragments where $B$. morio workers were collected (Tauhyl \& Urso-Guimarães 2012), the present study reported a high incidence of the parasitoid in worker bees, especially in the year of 2012. The study of the behavior and general development of the parasitoid fly larvae hosted in the bees was performed in an attempt to support and contribute to the knowledge of the biology of this important bee species.

\section{MATERIAL AND METHODS}

The bumble bees were collected in remaining fragments of semideciduous forest and Cerrado (2334'53.1"S $47^{\circ} 31$ '29.5') of the Federal University of São Carlos, at the Sorocaba Campus, in the municipality of Sorocaba, state of
São Paulo, Brazil. The inventorying of bees was systematically carried out from 2011 to April 2014, when almost 200 specimens (males, workers and queens) of Bombus morio were collected in order to determine the seasonal colony cycle. However, some bee specimens presented microtype fly larvae, which were then studied inside the host under laboratory conditions. The field activities were performed in the morning (9 a.m.) and in the afternoon (4 p.m.), using entomological nets. The specimens were conditioned in amber flasks and transported to the Laboratory of Structural and Functional Biology (LABEF), where they were maintained in a B.O.D. incubator $\left(24 \mathrm{~N}, 26^{\circ} \mathrm{C}\right)$ in order to obtain adult specimens of the parasite. Twenty females of $B$. morio were incubated for the purpose of verifying symptoms of parasitism and trying to develop the parasitoid in the adult bee. Bees presenting signs of decrease in motor activity or lethargy were narcotized and dissected. The metasoma of the bees was cut laterally along its entire length, but not removed completely. The bee-host specimens had their fly larvae measured in length and in diameter, in loco. The larvae were observed daily under a stereomicroscope (Zeiss - Stemi DV4), by carefully picking up the bee sternal integument.

\section{RESULTS AND DISCUSSION}

In two samplings carried out from summer through early winter (March to July, 2012), 12 specimens of Bombus morio were collected on flowers of Cassia sp. aff. mannii Aubrev., in the morning and other eight bees were collected on flowers of Macroptilium atropurpureum (DC.) Urb. in the afternoon. Among the 12 specimens collected in the morning, three females, after dissection, were found to have parasitoid fly larvae inside their metasoma. Amongst the eight specimens collected in the afternoon, one female was also parasitized. No such occurrence was observed in the collected males. Schmid-Hempel \& Schmid-Hempel (1996) examined 1123 Bombus pascuorum (Scopoli, 1763) workers and found an average of 417 larvae of Physocephala rufipes (Fabricius, 1781 ) among them, almost $42 \%$. This was about the same percentage observed for $B$. morio and it was also observed that mainly the females were parasitized.

After the dissection of 20 females in 2012, nine larval individuals of Physocephala sp. (Diptera, Conopidae) were found, one in each bee. In only one occasion, two early parasite larvae (L1) were found inside one bee. In all cases, only one larva reached the pupal stage and, under laboratory conditions, only one female completed the entire cycle to adult fly. Intra and inter-specific competition in conopids is a natural phenomenon, and one larva per host can develop successfully (Salt 1961; Schmid-Hempel \& Schmid-Hempel 1996). In 2013, the population of $B$. morio had a strong decrease and showed a recovery in 2014. In 2014, out of the 29 females collected in March, only one had been parasitized by a conopid fly larva.

The parasitism strategy of the conopid flies has proven to be very effective, since in the same study area Tauhyl \& Urso- 
Guimarães (2012) have observed only $0.01 \%$ of conopid frequency among 1437 individuals of 29 Diptera families. The high occurrence of conopid flies (4 individuals) was reported during offspring (November), when the first B. morio female workers became abundant in the field.

Judging from larval size and morphological characteristic (see Schmid-Hempel \& Schmid-Hempel 1996) during fly larval development, larval stages LO, L1, L2, L3 and PUP were observed in the laboratory. LO, not shown here, was defined as the stage right after the larvae had hatched from the eggs; in LO the larvae measured less than $1 \mathrm{~mm}$ in length. From L1 to L3, the larvae grew in length, with L1 larvae measuring 2.5 $\mathrm{mm}$ in length and L2, $3.5 \mathrm{~mm}$ (Fig. 2). From LO until L3, the parasitoid doubled in length $(4 \mathrm{~mm})$ and then began to develop both in length and in width, reaching the PUP stage with $10 \mathrm{~mm}$ in length and $7 \mathrm{~mm}$ in width (Fig. 2). From LO to late L2, the larva lodged inside the bee's abdomen was always found in the vertical position, following the minor axis of the abdomen, located at the proximal region, near the thorax (Marcondes et al. 2011). Thus, the early larval stages lodged in the dorsal portion of the inner abdomen, accommodating close to the terminal filaments of the ovaries, between the first and second terga. The larvae from LO to L2 (and early L3) were translucent (Fig. 1) and, at this stage, they probably consumed hemolymph from the abdomen hemocoel.

After the larvae reached $7 \mathrm{~mm}$, in L2, they rotated, positioning at the major axis of the bee's abdomen. From LO to L2, the larvae feed on almost all the internal organs of the bee abdomen. Late L3 and PUP larvae extended their buccopharyngeal apparatus and turned to the bee thorax internal opening for access to the bee's flight muscles. The posterior spiracles start to appear late into the L2 stage, and are very distinguishable in L3 and especially in PUP (Fig. 2). From L3 to PUP, the anal region presented typically two spiracles, with the sclerotization starting in late L3 and PUP (Townsend 1935). In L3 the spiracles may be completely developed or not. The last stage of larval development and the pupation stage are marked by the position of the larva inside the bee's abdomen, when it takes up the entire abdominal hemocoel, with its head turned toward the thorax and the spiracles turned toward the last abdominal segments. The larval rotation inside the bee's abdomen marks the beginning of pupation, with PUP having been well characterized. The PUP larvae measured $10 \mathrm{~mm}$ in length and $7 \mathrm{~mm}$ in diameter, with two dark reddish large spiracles and extended buccopharyngeal apparatus, and a whitish color, due the very well developed fat body, which can be observed through the translucent integument (Fig. 2). In all bee-hosts, the PUP became a pupa in less than $24 \mathrm{~h}$. The puparia were reddish in the first day, and grew gradually darker to maroon after about 30 days. The puparia occupied the whole abdominal hemocoel (Fig. 2A). When the pupal stage is finished, the imago fly emerges, creating a scission on the top of the cranial portion of the puparium (Fig. 2B) and leaving the bee's abdomen through the intersegmental membrane between the sterna.

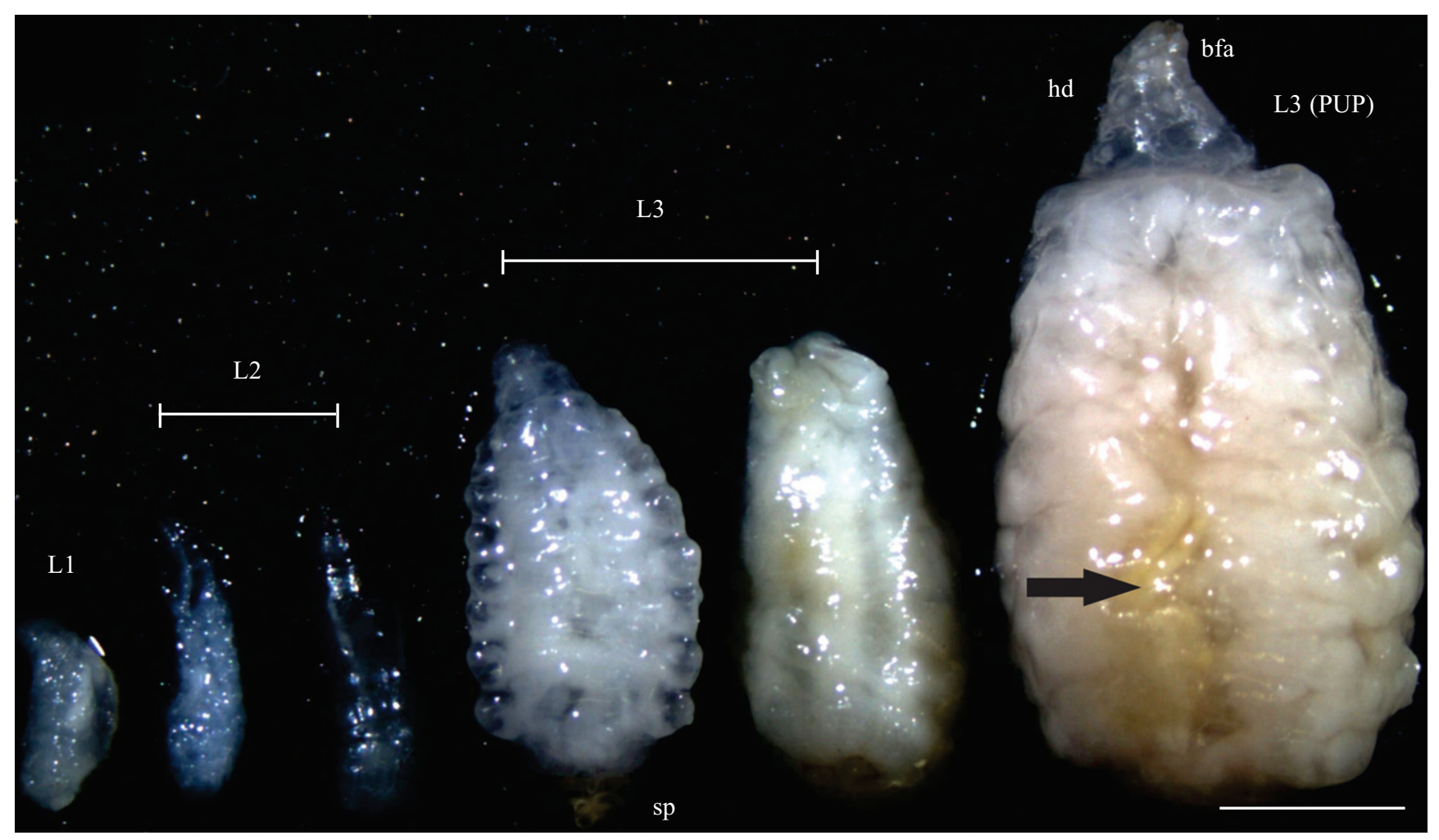

Fig. 1. Larval stages, L1, L2, and L3 with early spiracle ( $\mathrm{sp}$ ) development, of Physocephala sp. dissected from adult female workers of Bombus morio. Last L3 instar, or PUP, with the gut full of faeces, head (hd) with extended buccopharyngeal apparatus (bpa) and gut containing food (arrow). Scale bar: 0.25 cm. 

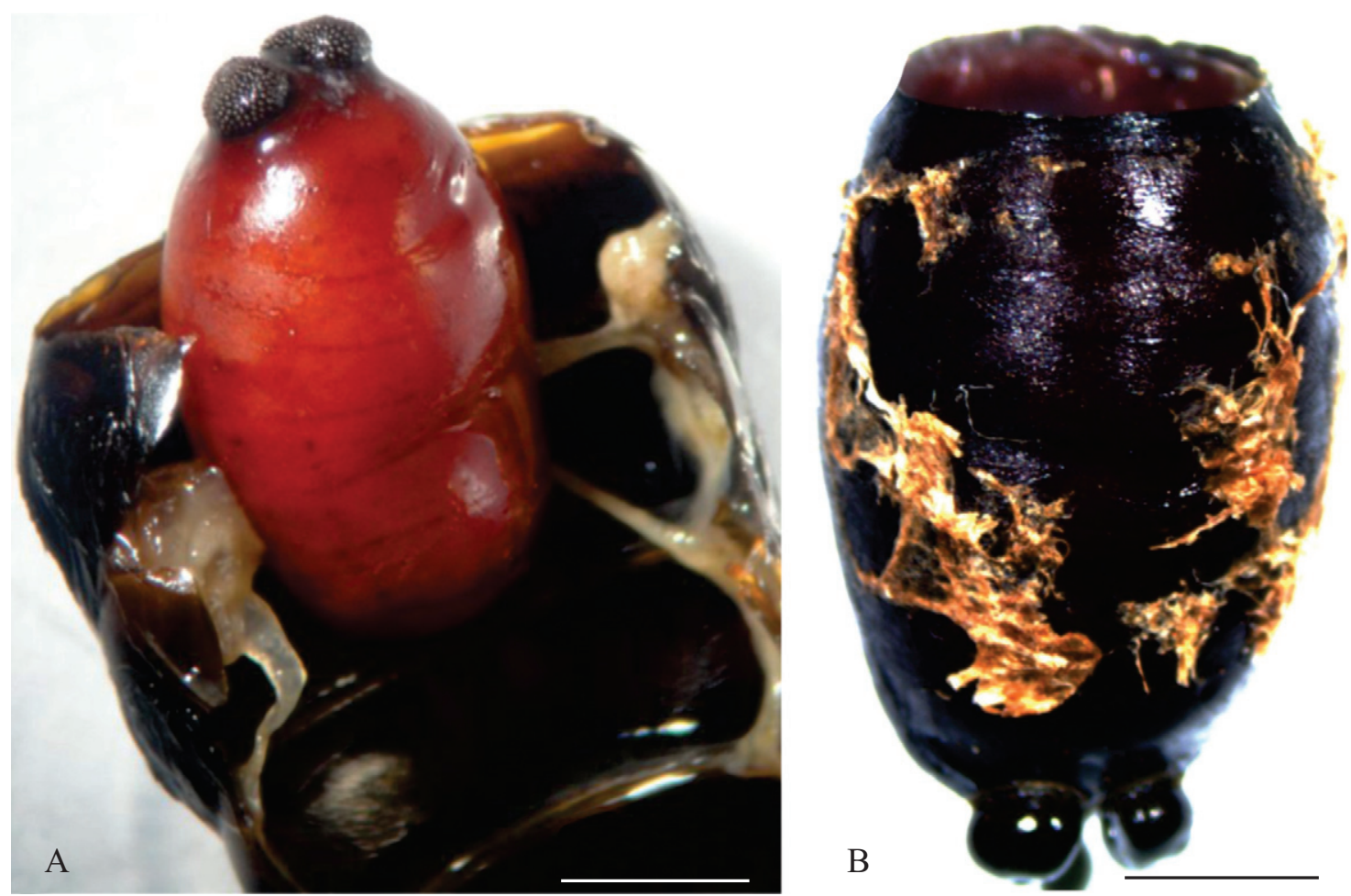

Fig. 2. A. Cocoon soon after pupation of Physocephala sp. lodged inside the bee's abdominal cavity (dissected in this micrograph). B. Cocoon opened by newly-emerged fly. Scale bars: A $=0.35 \mathrm{~cm}, \mathrm{~B}=0.25 \mathrm{~cm}$.

The bees did not show any signal of behavioral or morphological disturbance at the time of collection, in the field, not even those infected by parasitoids. After collection and under controlled conditions, they showed metabolism reduction and decreased motor activity followed by death, as described by Müller \& Schmid-Hempel (1993). This metabolism reduction is probably associated with the loss of internal organs, digested by the larvae as described by Caldano et al. (2008) for Conopidae in Centris, Bombus, Apis mellifera and other bee species. The results showed that the larvae feed on hemolymph at first, then on the host's visceral fat tissue and ovaries. When the larva is almost ready for pupation, the buccopharyngeal apparatus reaches the flight muscles.

From all bee hosts under study, only one adult parasite fly emerged from a female worker bee maintained in B.O.D. incubator, two reached the PUP stage and four pupated inside the worker bees. The adult fly presented all the taxonomic characteristics of the genus Physocephala Schiner, 1861, with a petiolate abdomen presenting with two long and narrow segments, and the others broader and shorter; anterior cross vein $\mathrm{r}-\mathrm{m}$ well beyond the middle of discal cell ( $\left.1^{\text {st }} \mathrm{M} 2\right)$; and hind femur irregularly thickened at the base (Camras \& Hurd 1957). They resemble solitary wasps, and their larvae are parasites of Sphecidae and aculeate bees, especially bumble bees (Stuke 2005; Caldano et al. 2008; Melo et al. 2008).

The parasite larva kept the host alive until L3 or PUP, when all the internal organs had already been digested and the cocoon took up the entire space of the inner abdomen.
This fact shows that the larva position during development was not a random event. During larval development, there were specific areas occupied by the endoparasite, starting in the proximal region and ending in the distal region of the bee-host's abdomen (Marcondes et al. 2011). The puparium is positioned along the largest axis of the host's abdomen and, after pupation, the adult emerges from between the sixth and fifth sterna. This strategy is necessary, once the adult parasite fly is relatively large and needs to emerge from the largest intersegmental membrane. The female fly oviposites on the tergites, but the imago emerges from the bee's sternites, as also observed by Caldano et al. (2008) and Melo et al. (2008). The duration of the larval and pupal stages were measured. The former was a period of 10 days, as described by Schmid-Hempel \& Schmid-Hempel (1996) for the same genus of Conopidae, and the interval between pupation and emergence was a period of 32 days.

When foraging or even resting on flowers, bees can become targets to conopid flies such as Physocephala (Caldano et al. 2008; Melo et al. 2008). On these occasions, according to Santos et al. (2008), Centris (Heterocentris) analis (Fabricius, 1804) can be parasitized by Conopidae females depositing their eggs between the intersegmental membranes of the abdominal tergites, which are extended, penetrating their ovipositor and depositing the egg to develop inside the adult bee's abdomen.

No species-level records of conopid parasitism for $B$. morio have been found in the literature. The bee genera known to be parasitized by conopids in the neotropics are Centris 
(Caldano et al. 2008; Santos et al. 2008), Bombus (SchmidHempel \& Müller 1991; Müller \& Schmid-Hempel 1993; Schmid-Hempel \& Schmid-Hempel 1996; Gillespie 2010; Cameron et al. 2011), and Eulaema (Rasmussen \& Cameron 2004), bees recognized by their large size. However, smaller bees can also be parasitized, such as those of the genus Euglossa (Melo et al. 2008).

\section{ACKNOWLEDGMENTS}

We thank FAPESP (11/17840-6, 14/04697-9), CAPES and CNPq. M.Sc. Sérgio Rodriguez Morbilo for identifying all the plant species visited by the bees during this research.

\section{REFERENCES}

Abrahamovich, A.H., Díaz, N.B. \& Morrone, J.J. 2004. Distributional patterns of the neotropical and Andean species of the genus Bombus (Hymenoptera: Apidae). Acta Zoológica Mexicana 20: 99-117.

Anderson, G.S. 2000. Minimum and maximum development rates of some forensically important Calliphoridae (Diptera). Journal of Forensic Sciences 45: 824-832.

Aldana, J., Cure, J.R., Almanza, M.T., Vecil, D. \& Rodríguez, D. 2007. Efecto de Bombus atratus (Hymenoptera: Apidae) sobre la productividad de tomate (Lycopersicon esculentum Mill.) bajo invernadero en la Sabana de Bogotá, Colombia. Agronomía Colombiana 25: $62-72$.

Biesmeijer, J.C., Roberts, S.P.M., Reemer, M., Ohlemüller, R., Edwards, M., Peeters, T., Schaffers, A.P., Potts, S.G., Kleukers, R., Thomas, C.D., Settele, J. \& Kunin, W.E. 2006. Parallel declines in pollinators and insect-pollinated plants in Britain and the Netherlands. Journal of Insect Conservation 313: 351-354.

Caldano, L.T.P., Serrano, J.C. \& Garófalo, C.A. 2008. Parasitismo por Physocephala (Diptera: Conopidae): um importante fator de mortalidade para fêmeas e machos de Centris (Heterocentris) analis (Hymenoptera, Apidae). In: Anais do VIII Encontro sobre Abelhas. Ribeirão Preto, São Paulo, p. 696. Available at: http://myrtus.uspnet.usp. br/bioabelha/images/pdfs/pdfs_publicacoes3.1/conferencias_nacionais/ caidano_et_al_2008.pdf (accessed 13 June 2014).

Cameron, S.A., Whitfield, J.B., Cohen, M. \& Thorp, N. 1999. Novel use of walking trails by the Amazonian bumble bee, Bombus transversalis (Hymenoptera: Apidae). University of Kansas Natural History Museum Special Publications 24: 187-193.

Cameron, S.A., Lozier, J.D., Strange, J.P., Koch, J.B., Cordes, N., Solter, L.F. \& Griswold, T.L. 2011. Patterns of widespread decline in North American bumble bees. Proceedings of the National Academy of Sciences of the United States of America 108: 662-667.

Camras, S. \& Hurd, P.D., Jr. 1957. The conopid flies of California (Diptera). Bulletin of the California Insect Survey 6: 19-49.

Cataloque of Life. 2014. Annual Checklist. Available at: http://www. catalogueoflife.org/annual-checklist/2014/(accessed 13 August 2014).

Cortopassi-Laurino, M., Knoll, F.R.N., Imperatriz-Fonseca, V.L. 2003. Nicho trófico e abundância de Bombus morio e Bombus atratus em diferentes biomas brasileiros, p. 285-295. In: Melo, G.A.R. \& Alvesdos-Santos, I. (eds.). Apoidea Neotropica: Homenagem aos 90 Anos de Jesus Santiago Moure. Criciúma, Editora UNESC, 320 p.

Cortopassi-Laurino, M., Imperatriz-Fonseca, V.L., Roubik, D.W., Dollin, A., Heard, T., Aguilar, I., Venturieri, G.C., Eardley, C. \& NogueiraNeto, P. 2006. Global meliponiculture: challenges and opportunities. Apidologie 37: 275-292.

De Jong, D. 2009. Disappearance of bees, farm pesticides affect insects, crops and human health. Scientific American Brasil 84: 48-49.

Evans, E., Thorp, R., Jepsen, S. \& Black, S.H. 2008. Status review of three formerly common species of bumble bee in the subgenus
Bombus. The Xerces Society. p. 63. Available at: http://www.xerces. org/wp-content/uploads/2009/03/xerces_2008_bombus_status_ review.pdf (accessed 13 June 2014).

FAO - Food and Agriculture Organization of the United Nations 2008 Rapid assessment of pollinators' status. A contribution to the international initiative for the conservation and sustainable use of pollinators. Available at: http://www.fao.org/uploads/media/raps_2.pdf (accessed 13 June 2014).

Gillespie, S. 2010. Factors affecting parasite prevalence among wild bumblebee. Ecological Entomology 35: 737-747.

Grixti, J.C., Wong, L.T., Cameron, S.A. \& Favret, C. 2009. Decline of bumble bees (Bombus) in the North American Midwest. Biological Conservation 142: $75-84$

Klein, A.M., Vaissiere, J.H., Cane, J.H., Steffan-Dewenter, I., Cunningham, S.A., Kremen, C. \& Tscharntke, T. 2007. Importance of pollinators in changing landscapes for world crops. Proceedings of the Royal Society of London B 274: 303-313.

Kosior, A., Celary, W., Olejniczak, P., Fijal, J., Król, W., Solarz, W. \& Plonka, P. 2007. The decline of the bumble bees and cuckoo bees (Hymenoptera: Apidae: Bombini) of western and central Europe. Oryx 41: 79-88.

Kronka, F.J.N., Nalon, M.A., Matsukuma, C.K., Kanashiro, M.M., Ywane, M.S.S.-I., Pavão, M., Durigan, G., Lima, L.M.P.R., Guillaumon, J.R., Baitello, J.B., Borgo, S.C., Manetti, L.A., Barradas, A.M.F., Fukuda, J.C., Shida, C.N., Monteiro, C.H.B., Pontinha, A.A.S., Andrade, G.G., Barbosa, O. \& Soares, A.P. 2005. Inventário florestal da vegetação natural do Estado de São Paulo. São Paulo, Secretaria do Meio Ambiente; Instituto Florestal; Imprensa Oficial, 200 p.

Léon, L.A., Torres, O.R. \& Parra, N.G. 1991. Distribución altitudinal del género Bombus en Colombia (Hymenoptera: Apidae). Trianea 4: 541550

Marcondes, M., Pinheiro F.A.C.G., Morbiolo, S.R., Camargo, D.A., Cláudio, V.C., Sampaio, G. \& Abdalla, F.C. 2011. Flying with the enemy: An endoparasitic fly larva in Brazilian bumblebees. International Journal of Biodiversity and Conservation 3: 383-385.

Martins, A.C. \& Melo, G.A.R. 2010. Has the bumblebee Bombus bellicosus gone extinct in the northern portion of its distribution range in Brazil? Journal of Insect Conservation 14: 207-210.

Melo, G.A.R., Faria, L.R.R., Marchi, P. \& Carvalho, C.J.B. 2008. Small orchid bees are not safe: parasitism of two species of Euglossa (Hymenoptera: Apidae: Euglossina) by conopid flies (Diptera: Conopidae). Revista Brasileira de Zoologia 25: 573-575.

Michener, C.D. 2000. The Bees of the World. Baltimore, The Johns Hopkins University Press, 913 p.

Moure, J.S. \& Sakagami, S.F. 1962. As mamangabas sociais do Brasil (Bombus Latreille) (Hymenoptera, Apoidea). Studia Entomologica 5: $65-194$

Müller, C.B. \& Schmid-Hempel, P. 1993. Exploitation of cold temperature as defence against parasitoids in bumblebees. Nature 363: 65-67.

Plischuk, S., Martín-Hernández, R., Prieto, L., Lucía, M., Botías, C., Meana, A., Abrahamovich, A.H., Lange, C. \& Higes, M. 2009. South American native bumblebees (Hymenoptera: Apidae) infected by Nosema ceranae (Microsporidia), an emerging pathogen of honeybees (Apis mellifera). Environmental Microbiology Reports 1: 131-135.

Pywell, R.F., Warman, E.A., Hulmes, L., Hulmes, S., Nuttall, P., Sparks, T.H., Critchley, C.N.R. \& Sherwood, A. 2006. Effectiveness of new agrienvironment schemes in providing foraging resources for bumblebees in intensively farmed landscapes. Biological Conservation 129: 192-206.

Rasmussen, C. \& Cameron, S.A. 2004. Conopid fly (Diptera: Conopidae) attacking large orchid bees (Hymenoptera: Apidae: Eulaema). Journal of the Kansas Entomological Society 77: 61-62.

Sakagami, S.F. 1976. Specific differences in the bionomic characters of bumblebees. A comparative Review. Journal of the Faculty of Science Hokkaido University Series VI. Zoology 20: 390-447.

Salt, G. 1961. Competition among insect parasitoids. Mechanisms in biological competition. Symposia of the Society for Experimental Biology 15: 96-119. 
Santos, A.M., Serrano, J.C., Couto, R.M., Rocha, L.S.G., Melo-Patiu, C.A. \& Garófalo, C.A. 2008. Conopid flies (Diptera: Conopidae) parasitizing Centris (Heterocentris) analis (Fabricius) (Hymenoptera: Apidae, Centridini). Neotropical Entomology 37: 606-608.

Schmid-Hempel, R. \& Müller, C.B. 1991. Do parasitized bumblebees forage for their colony? Animal Behaviour 41: 910-912.

Schmid-Hempel, R. \& Schmid-Hempel, P. 1996. Larval development of two parasitic flies (Conopidae) in the common host Bombus pascuorum. Ecological Entomology 21: 63-70.

Stuke, J.-H. 2005. Bestimmung und Taxonomie der palaarktischen Conopiden (Diptera) 1. Teil: Die Physocephala rufipes-Artengruppe.
Studia Dipterologica 12: 369-384

Tauhyl, L.G.M. \& Urso-Guimarães, M.V. 2012. Levantamento da dipterofauna em fragmentos vegetacionais da UFSCar-campus Sorocaba, SP, Brasil. Revista Trópica: Ciências Agrárias e Biológicas 6: 79-88.

Townsend, C.H.T. 1935. New muscoid genera, mainly from the Neotropical region. Revista de Entomologia 5: 68-74.

Williams, P.H. 1982. The distribution and decline of British bumble bees (Bombus Latr.). Journal of Apicultural Research 21: 236-245.

Williams, P.H. 2005. Does specialization explain rarity and decline among British bumblebees? A response to Goulson et al. Biological Conservation 122: 33-43. 